\title{
IMPLEMENTASI SISTEM INFORMASI MANAJEMEN DALAM MANAJEMEN SEKOLAH
}

Afrilya Safitri

\author{
Afrilyasafitri@gmail.com
}

Abstrak

Sistem informasi manajemen sangat diperlukan dalam meningkatkan mutu pembelajaran dikarenakan sistem informasi ini sangat berpengaruh dalam melaksanakan pembelajaran, dengan adanya sistem informasi manajemen ini belajar mengajar dapat berjalan dengan baik, salah satunya proses belajar mengajar jarak jauh antara peserta didik dengan guru, melihat nilai secara online, mengambil absen online, mengirimkan berkas tugas online, metode pembayaran online dan semua dilakukan dengan menggunakan teknologi informasi sehingga membuat para peserta didik itu semakin praktis dalam belajar .

Kata kunci : sistem informasi manajemen , mutu pembelajaran.

\section{PENDAHULUAN}

\section{A. Latar Belakang}

\section{Pengertian Sistem Infomasi Manajemen}

sistem informasi manajemen adalah suatu sistem yang dirancang untuk menyediakan informasi guna mendukung pengambilan keputusan pada kegiatan manajemen dalam suatu organisasi.(Ajie, n.d.) dapat disimpulkan bahwa sistem informasi manajemen adalah suatu sistem yang banyak mengeluarkan informasi secara detail , mengumpulkan, menyediakan informasi yang dibutuhkan oleh seseorang atau suatu organisasi dan sebagai menunjang proses belajar mengajar agar berjalannya sesuai dengan yang diinginkan serta mencapai tujuan yang efektif dan efesien.

\section{Tujuan Sistem Informasi Manajemen}

Tujuan dari dibangunnya informasi berupa aplikasi sistem informasi pendidikan adalah :

1. Membantu seluruh bagian yang berperan didunia pendidikan untuk mengumpulkan data serta informasi dalam mengambil keputusan kepemimpinan agar bisa menyajikan data yang simple.

2. Pemberi informasi harus bertanggungjawab kepada publik agar memberikan informasi secara transparan yang tidak ditutupi oleh media maupun orang - orang dalam sehingga masa bisa mengetahui informasi yang lebih jelas .

3. Memanfaakan guru yang mengikuti pelatihan dengan cara Memberikan informasi kepada peserta didiknya agar berguna untuk perbaikan berkelanjutan.

Informasi dipergunakan untuk memberikan informasi yang mudah kepada peserta didik agar dapat melakukan perhitungan harga dengan cara menjual belikan produk secara mudah . 
Secara umum tujuan sistem informasi manajemen adalah untuk menyediakan informasi , untuk mengambil keputusan , mengetahui perencanaan, pengendalian, evaluasi, dalam menyediakan suatu produk atau jasa yang dilakukan oleh karyawan untuk managernya.

\section{Manfaat Sistem Informasi Manajemen}

a. Meningkatkan data secara efektif dan akurat agar tidak melenceng terhadap informasi yang didapatkan .

b. Memudahkan manajemen dengan melakukan perencanaan, pengorganisasian, pengendalian, pengawasan, pengarahan kepada karyawan yang memiliki hubungan yang kerja .

c. Dapat meningkatnya sumber daya manusia agar dapat bekerja dengan ,maksimal dan tercapai tujuan secara efektif dan efisien.

d. Dapat meningkatnya produktivitas dan hematnya biaya dalam suatu organisasi.

\section{Fungsi Sistem Informasi Manajemen}

a. Memudahkan informasi sehingga menjadikan hemat biaya dan menjadikan suatu proses lebih efektif.

b. Menyajikan data tepat waktu efektif serta efesien.

c. Terkoordinirnya sistem kerja serta melancarkan semua kegiatan

d. pengembangan suatu sistem yang efesien .

\section{Implementasi Sistem Informasi Manajemen Dalam Manajemen Sekolah}

Penerapan sistem informasi manajemen disekolah sangat diperlukan karena dapat membantu proses belajar mengajar aik guru maupun peserta didik yang ada disekolah tersebut . dikarenakan juga mengikuti perkembangan zaman oleh karena itu teknologi sangat berpengaruh sekali terhadap peserta didik dan guru. Dan dengan menerapkan sistem informasi manajemen ini juga dapat meningkatkan hasil kinerja guru dan peserta didik yang dalam belajar mengajarnya makin bersemangat dan menambah pengetahuan tentang teknologi . manfaat dengan adanya sistem informasi manajemen ini adalah agar para guru tidak perlu lagi repot-repot untuk membuat raport manual dengan berjalannya ini maka guru mudah memasukan nilai melalui excel dan dikirim ke sistem informasi manajemen.

Dampak meningkatnya impelementasi sistem informasi manajemen pendidikan terhadap etika dan sosial meningkatnya penggunaan. Disatu sisi dan disisi lain perkembangan teknologi informasi, khususnya komputer menimbulkan masalah baru . teknologi informasi yang berkembang cepat membawa dua dampak positif dan negatif . namun terlepas dari dampak tersebut, terlihat bahwa dampak organisasi khususnya organisasi pendidikan menyambut dengan baik perkembangan teknologi informasi . hal ini dapat dibuktikan dengan semakin banyaknya sekolah dan universitas yang makin banyaknya menggunakan teknologi informasi. Banyak sekali manfat serta dampak positif yang diperoleh dari penerapan teknologi informasi. Namun, sekolah dan universitas juga harus mempersiapkan strategi dampak negatif dari penerapan teknologi informasi yaitu 
pengurangan tenaga kerja yang nantinya berimbas pada meningkatnya angka pegangguran . untuk itu diperlukan suatu strategi untuk mengatasi masalah tersebut.salah satu caranya adalah memadukan antara teknologi informasi dengan sumber daya manusia agar nantinya tidak meningkatkan pengangguran . (nopredi basrul, n.d.)

(Ramadanti, Gita Bonita; Sabandi, 2019) terdapat beberapa presepsi terhadap penerapan sistem informasi manajemen :

1. presepsi pegawai terhadap penerapan sistem informasi manajemen kepegawaian (SIMPEG) dilihat dari aspek input .

input merupakan aktivitas utama dalam penerapan sim berbasis komputer karena aktivitas input adalah proses meamasukan data kedalam sebuah sistem yang telah dirancang oleh organisasi dalam manajemen data yang kemudian akan diproses untuk mendapatkan sebuah informasi yang berguna bagi organisasi.

2. Presepsi pegawai terhadap penerapan sistem informasi manajemen kepegawaian (SIMPEG) dilihat dari aspek proses .

Proses merupakan perubahan atau alat transformasi dari masukan menjadi keluaran yang berguna. Untuk mendapatkan keluaran yang berguna bagi pengguna SIMPEG tentu saja pada saat proses mengubah masukan menjadi keluaran harus dilakukan sebaik mungkin. Oleh karena itu pada aktivitas proses ada beberapa hal yang harus dilakukan, yaitu : 1). Pengoahan data . dan 2). Penyimpanan data .

3. Presepsi pegawai terhadap penerapan sistem informasi manajemen kepegawaian (SIMPEG) dilihat dari aspek output.

Output merupakan hasil dari aktivitas yang telah dilakukan . dalam pengaplikasiannya sim output yang dihasilkan dalah informasi. Informasi (output) yang baik tentu harus memiliki kualitas yang baik pula karena kualitas menunjukan kepada ukuran penilaian atau penghargaan yang diberikan atau dikenakan. Untuk itu dalam pemanfaatan informasi yang dihasilkan SIMPEG, sebaiknya pegawai memperhatikan beberapa kriteria yang terkandung dalam sebuah informasi yang meliputi : 1). Kepadatan informasi , 2). Relevan , 3). Akurat , 4). Kejelasan.

(dewi asnita putri, n.d.) penerapan sistem informasi manajemen disekolah tentunya tidak terlepas dari berbagai macam kendala dan permasalahan yang terjadi . adapun fenomena presepsi guru yang terlihat dalam meningkatkan mutu pendidikan berbasis data disekolah dasar islam terpadu ash-haabul kahfi sebagai berikut :

1. Banyaknya guru senior yang kurang tertarik untuk belajar teknologi baru.

2. Mindset guru senior yang beranggapan bahwa mereka takkan pernah bisa untuk menggunakan teknologi selamanya.

3. Pola pikir instan dan mudah menyerah dalam menggunakan teknologi pada pembelajaran dan penyelesaian administrasi guru. 
4. Menimnya fasilitas kantor yang hanya mempunyai satu komputer, satu printer, dan satu infokus, sehingga membuat para guru masuk list antrian pada pembelajaran berbasis teknologi.

5. Sinyal wifi yang kurang bagus dikarenakan letak geografis yang jauh dari jalan raya utama.

Dengan adanya sim yang memadai sekolah sangat berkembang sesuai dengan perkembangan zaman , tetapi masih ada disekolah yang kurang memadai dan banyak juga terdapat hambatan - hambatan dalam menggunakan sistem informasi manajemen disekolah seperti :

1. Kurangnya pemahaman terhadap komputer

2. Kurangnya pemahaman guru terhadap jurusan teknologi yang ia ajarkan

3. Komputer harganya masih banyak yang belum dapat menjangkau sehingga msih banyak juga peserta didik yang belum mempunyai komputer .

4. Kurangnya jaringan dan perangkat - perangkat yang ada disekolah .

5. Jumlah petugas sim yang masih terbatas sehingga banyak guru yang mengambil petugas sim dari bidang studi yang lain sehingga disuruh untuk menjadi seorang petugas sim atau jurusan yang tidak sesuai dengan yang diajarkan dan melenceng dari jurusan yang sebenarnya.

\section{Kesimpulan}

Sistem informasi manajemen adalah suatu proses untuk menunjang atau mengelola pembelajaran agar pembelajaran tersebut dapat berjalan dengan lancar dan dapat mencapai tujuan yang efektif dan efesien serta dapat memudahkan seseorang dalam melakukan segala hal dengan cara yang simple .

sistem teknologi informasi sangat diperlukan karena dapat membantu meringankan kerja gguru dan peserta didik dalam hal belajar mengajar dan juga sesuai dengan perkembangan zaman . dengan adanya teknologi informasi ini maka dengan mudahnya melakukan, mengirim tugas dengan sangat gampang . dan juga ada dampak negatifanya yaitu semakin banyak tingkat pengangguran . maka agar tidak terjadinya banyak pengangguran alangkah baiknya antara teknologi informasi dengan sumber daya manusia dipadukan agar mengurangi tingkat pengangguran . 


\section{saran}

hanya saja terdapat keterbatasan sistem jaringan dan alat teknologi disekolah tersebut dapat menghambatnya pembelajaran yang sesuai dengan perkembangan zaman . oleh sebab itu diharapkan kepada kepala sekolah untuk melengkapi teknologi disekolah agar sistem belajar mengajarnya dapat berjalan dengan lancar dan efektif serta efisien.

\section{Daftar Pustaka}

Ajie, miyarso dwi. (n.d.). sistem informasi konsep dasar. 1-9.

dewi asnita putri, ahmad sabandi. (n.d.). persepsi guru dalam meningkatkan mutu pendidikan berbasis sistem informasi manajemen di sekolah dasar negeri 08 batang anai.

nopredi basrul. (n.d.). sistem informasi manajemen pendidikan.

Ramadanti, Gita Bonita; Sabandi, A. (2019). persepsi pegawai terhadap penerapan sistem informasi manajemen kepegawaian (simpeg) di badan kepegawaian daerah provinsi sumatera barat gita. Pedagogik, Jurnal Ilmiah Imu Pendidikan, $8(2), 188$. 